\title{
The Role of Environmental Tax in Flood Reduction: A Study of Lagos State "Nigeria”
}

\author{
Uwuigbe Uwalomwa, Uwuigbe Olubukunola Ranti and lyoha Francis \\ Department of Accounting, School of Business, College of Development Studies, \\ Covenant University, Ota, Nigeria \\ Correspondence should be addressed to: Uwuigbe Uwalomwa; \\ uwalomwa.uwuigbe@covenantuniversity.edu.ng
}

Received date: 24 September 2013; Accepted date: 8 January 2014; Published date: 03 March 2015

Copyright (C) 2015. Uwuigbe Uwalomwa, Uwuigbe Olubukunola Ranti and lyoha Francis. Distributed under Creative Commons CC-BY 4.0

\begin{abstract}
Cities in Nigeria are generally characterized by poor drainage and are therefore subject to flooding. Particularly affected are cities like Lagos, Ibadan, Aba, Calabar, Yenagoa, etc. An estimated 25 million people or $28 \%$ of Nigeria's population live in the coastal area and are at risk from flooding. To this end, environmental taxes have been proposed to address a wide range of issues including waste disposal, water pollution and air emissions. This study looked at environmental tax, and how it can be used as a tool for flood reduction in Nigeria. The research covers the local governments which are majorly affected by flood in Lagos state and copies of questionnaire were administered to the selected samples who are residents. The Spearman Rank Order Correlation which is a non-parametric test was used to measure the degree of association between the dependent and the independent variables. The findings revealed that there is a moderate positive correlation ( $R s=.398, p<.005)$ between the imposition of environmental tax on nylon packages and the reduction of flood and it is significant at 0.01 . The study concludes that the implementation of environmental taxes on nylon packaging companies will lead to a reduction in the use of nylon as the major packaging system in Nigeria. The study therefore recommends that there should be a change in the packaging system in Nigeria as most of our products are made by nylon. The adoption of paper bags or cloth bag which has been adopted in developed countries especially in England should be emphasized.
\end{abstract}

Keywords: Environmental tax, flood, global warming, Nigeria

\section{Introduction}

In recent years, tax payment has become a burden on the payers especially in developing economies. This is because people believe that there is no reward accruing from payment of tax. A policy issue that has been of particular interest in recent years is green tax reform, which involves increasing taxes on the use of the environment and reducing taxes on other tax

Cite this Article as: Uwuigbe Uwalomwa, Uwuigbe Olubukunola Ranti and Iyoha Francis (2015), " The Role of Environmental Tax in Flood Reduction: A Study of Lagos State "Nigeria" ", Journal of South African Business Research, Vol. 2015 (2015), Article ID 645670, DOI: 10.5171/2015.645670 
bases, especially labour (Coxhead \& Chan, 2011).

With the increment in the taxes on the use of environment and reduction of taxes in other areas, there will be more urgency on the part of individuals to pay tax because they will believe that there are benefits accruing to them since the tax being paid has something to do with their environment (Fullerton, 1996).

When the tax is imposed on a polluting or environmentally harmful substance or activity, it introduces an economic cost that the polluter will take into account when making the decision on whether or not to carry on the activity (Sollund, 2007; Uwuigbe, 2012).

Environmental challenges increase the pressure on governments to find ways to ease environmental damage while minimising harm to economic growth. Some of the tools at government's disposal in reducing environmental damage include; regulations, information programmes, innovation policies, environmental subsidies and environmental taxes. Taxes and innovation programmes in particular are a key part of this toolkit (OECD, 2011).

Furthermore, environmental taxes have been successfully used to address a wide range of issues including waste disposal, water pollution and air emissions. Environmental taxes used anywhere in the world are part of a set of environmental policy tools known as economic or Incentive - based instruments (European Environment Agency, 2000). Environmental taxes have many important advantages, such as environmental effectiveness, economic efficiency, the ability to raise public revenue and transparency. Environmental taxes can be extremely effective when they are properly designed, levied close to the environmentally damaging pollutant or activity and are also set at an adequate rate (OECD, 2011). Taxes on environmentally harmful behaviour can be further seen to have the potential of raising revenues for governments.

From the aforementioned, we can say that taxing on waste disposal which is a major cause of flood in Lagos State rather than on labour might be more appealing to individuals paying tax. Improper disposal of waste has also been seen to contribute to the effects of flood. Often, people dump refuse in drains and even on major roads. Some throw sachets of water and plastic bottles inside the gutters. The rubbish then blocks the drains whenever there is rain and causes flooding (Aderogba, 2012; Uwuigbe, 2012).

Nigerian towns are generally characterized by poor drainage and are therefore subject to flooding. Particularly affected are such towns as Lagos, Ibadan, Aba, Calabar, Maiduguri, Port-Harcourt, etc. An estimated 25 million people or about $20 \%$ of Nigeria's population live in the coastal area and are at risk from flooding (Dia, Wernerman, Grigoryan, Becch \& Jung, 2012; Uwuigbe, Jimoh \& Daramola, 2013).

This study looked at environmental tax and how it can be used to control flood in Nigeria. There is a wide variety of causes of flooding in Lagos State, but this research work is based on waste disposal as a major cause of flood.

\section{Statement of Research Problem}

Environmental disasters have become common phenomenon in the world as analysts (Uwuigbe, 2009; Aderogba, 2012) have argued that the environment was only responding to the abuses heaped on it by man's activities. These abuses include poor environmental planning policies, poor management of wastes, inadequate drains for the built up areas and others. For years, Lagos state has adopted alternative system of refuse disposal in order to relieve Lagos streets of solid waste, but the outcome of different choice of alternatives is rather calling for a better organized and result 
oriented approach to refuse disposal (Olusegun, 2012).

Waste dumping and inadequate waste management attempts are having adverse impact on the environment and on humans in Nigerian coastal cities (Omole \& Isiorho, 2011). Olufowobi (2012) opined that the refuse collected by cart pushers in each neighbourhood is always dumped into canals close to them at night, which is a case of being penny wise but pound foolish. This is because all the waste disposed by cart pushers and dumped into canals will eventually be washed back to homes and streets whenever it rains.

However, the issue of concern in this study is that the effect of improper disposal of waste has not been adequately examined as a major cause of flood. In Nigeria, our packaging system is mainly nylons or plastic bags, and this nylon or plastic bags represents a major percentage of waste, which is not well disposed thereby littering our environment. Nylons or plastic bags do not easily decompose because they are made out of non-biodegradable substances, that is polyethylene which are durable and do not rot. Scientists believe that it could take up to 1000 years for nylons/plastic bags to decompose on land and 450 years in water (Agidee, 2013).

Academic researchers have focused on taxes concerned with energy, air, water pollution \& industrial wastes in the oil and gas industry but few works have been done in the area of disposal of packaging materials. This study therefore focused on waste, but attention is on product taxing.

\section{Scope of the Study}

The research could not cover all the coastal regions in Nigeria which are affected by flood; it is therefore limited to Lagos State. This is because; according to Etuonovbe (2011) between 1970 till date, Lagos state has over 300,000 displaced people as a result of flood. The research covers the local governments which are majorly affected by flood in Lagos (Agege, Ajeromi-Ifelodun, Alimosho, Eti-osa, Mushin, Somolu, OshodiIsolo and Epe). A total of 400 respondents were covered (i.e. 50 from each local government)

\section{Objectives of the Study}

The overall objective of this research is to examine how environmental tax can be applied to prevent flood in Nigeria. The specific objectives include:

1. To ascertain the extent to which the imposition of environmental tax on nylon packaging can reduce flood in Nigeria.

2. To ascertain the extent to which the enlightenment of people on waste disposal can reduce flood.

\section{Research Hypotheses}

For the purpose of this research, the hypotheses to be tested are stated in there null forms.

1. $\mathrm{H}_{0}$ : There is no significant relationship between the imposition of environmental tax on nylon packaging and flood reduction.

2. $\mathrm{H}_{0}$ : There is no significant relationship between the enlightenment of people on waste disposal and the reduction of flood.

\section{Literature Review}

Environmental issues have emerged in recent decades as a major aspect of discussion in the problems of economic growth and development (Uwuigbe 2009). Natural disasters are prevalent in countries all over the world with Nigeria not being an exception. Some countries experience terrible disasters like hurricane, storm, tsunami and so on and this has led to many losses. Floods are among the most 
devastating natural disasters in the world, claiming more lives and causing more property damage than any other natural phenomena. In Nigeria, flood affects and displaces more people than any other disaster; it also causes more damage to properties. At least 20 per cent of the population is at risk from one form of flooding or another (Etuonovbe, 2011).

\section{Principles and Practice of Environmental Tax}

Environmental tax means to collect taxes from impersonal entities or individuals which are engaged in developing, defending or utilizing environmental resources, according to the degrees of the exploitation, pollution or protection of the environmental resources (Wang, Ge, Gao \& Zhao, 2005).

In recent years, there has been a resurgence of interest in taxation, especially for dealing with the problems of global warming and pollution (Nye, 2008). For most of the environmental problems encountered, well designed fiscal policies are the most natural instruments for reflecting environmental damages into the price of products and nonmarket activities (Ojeifo, \& Uwadie, 2001).

Taxation also delivers what is termed a "double dividend" as revenue raised through taxes on environmental "bad" are recycled to reduce taxes on economic "goods" for example on labour (Hasson, Leiman \& Visser, 2007). According to the traditional Pigouvian framework, environmental taxes should equal marginal damages and be levied directly on the source of emissions. However, the framework has little to say about appropriate revenue use, as it leaves aside other sources of distortion in the economy so there is no scope for efficiency-enhancing revenue recycling ((Alcalde, Corchon \& Moreno, 1998).

On a general note, the main theory of environmental tax is based on the fact that "The polluters should pay" in the sense that the source of the pollution is where the tax is imposed.

The Need for Environmental Tax

According to European Environment Agency (1996:15-18), the following are the major reasons for environmental tax:

\section{Bringing 'Externalities' into Prices}

The main economic reason for using taxes in environmental policy is to bring the costs of pollution and other costs of using the environment called externalities- into the prices of the goods and services produced by economic activity. Internalising external environmental costs is the main reason for using environmental taxes instead of regulations. They incorporate the costs of environmental services and damages directly into the prices of the goods, services or activities which give rise to them. This also helps to implement the Polluter Pays Principle and to integrate economic, fiscal and environmental policies.

\section{Minimising Pollution Control Costs}

A regulation on pollution control usually expects all polluters to reduce their pollution by the same extent, irrespective of their costs of doing so. An environmental tax allows each polluter to decide whether it is cheaper to pay the tax or to reduce pollution. Those polluters who face the highest costs of pollution reduction will tend to pay more of the tax whilst those facing low reduction costs will reduce pollution instead.

\section{Encouraging Innovation}

If the prices of fossil fuel energy, water or waste are increased through environmental taxes then this can encourage new ways of meeting needs. Such innovation can lead to new technologies, processes and products. For example, the US tax on CFCs helped to encourage the development of substitute chemicals that were then exported. Similarly, the Swedish tax on sulphurous diesel helped to encourage the development of new, less 
polluting fuels. For producers, they may act as a spur to innovation. When energy, water and raw materials, as well as solid, fluid or volatile emissions become taxed, taxpayers will develop new modes of production, transportation, housing, energy use and general consumption to reduce their tax liability. This helps to achieve more 'ecoefficiency'; to implement the precautionary principle; and to improve both sustainability and international competitiveness, where tomorrow's products depend on today's innovations.

\section{Raising Revenue}

Given that producers and consumers will probably not cease entirely the activities that are being taxed; the taxes and charges will raise revenues. These may be used to address environmental problems directly; or they may be used to subsidise producers or consumers to shift to more environmentallyfriendly activities, providing a second incentive for environmental improvement. They may also be applied to other government purposes, allowing, for the same level of government expenditure to be reduced with the objective of increasing employment and overall economic welfare.

\section{Taxes and Waste Management}

Although waste management has perhaps not been the high-profile focus of environmental issues in the way that transport or energy use has, there has been a significant change in household behaviour in recent years in the UK (Fullerton, Leicester \& Smith, 2007). Waste generation is a natural consequence of human, ecological and industrial processes. It increases proportionately with consumption, scientific and technological activities (Akinbola, 2009). Considerable public concern about the environment and the environmental "sustainability" of current patterns of production and consumption focuses on the generation and disposal of waste (Fullerton et al., 2007).
The result of some activities leaves the ecosystem worse-off comparatively. Most of such activities come through the release of waste as well as the extraction of environmental resources (Kasum, 2010). Of all environment problems in towns and cities, refuse disposal system and management is obviously the most visible (Ojeifo \& Uwadie, 2001). In Nigeria for example, the packaging system is mainly nylons and plastics and this constitutes waste and these products after being used are not properly disposed. The products thereby constitute in littering of the whole environment and when flood comes, they will lead to the blockage of roads and drainages. Waste deposited in gutters ordinarily do not allow the free flow of erosion waters, the effect is that some areas are flooded during rainfall and may not be convenient for passage for some time (Ojeifo \& Uwadie, 2001). Almost every nook and cranny in Nigeria is littered with sachet water nylon, popularly called "pure water", the large volume of which in ordinary parlance, constitutes pollution and termed negative externality or economic 'bad' in economics (Babatunde \& Biala, 2010). Eurostat (2001) states that the tax base for waste management includes waste management in general (e.g. collection or treatment taxes) and waste management, individual products (e.g. packaging, beverage containers).

\section{Methodology}

The population for this research work comprises of residents of Lagos State. Residents were chosen as the population of this research because the environmental tax is targeted at the household sector and they are always the victims of flood. The target population for this study comprised of residents who are 18 years and above. According to 2006 population census conducted by the National Population Commission, over 8 million populace of Lagos state are resident in the eight identified local governments selected for this research. In view of the researcher's inability to reach out to the entire population, the 
Yaro Yamani formula is used in determining the population size.

Using the Yaro Yamani formula: $\mathrm{n}=\mathrm{N} /[1+$ $\left.\left(\mathrm{Ne}^{2}\right)\right]$

Where $\mathrm{n}=$ is the sample size

$\mathrm{N}=$ is the population

$\mathrm{e}=$ is the error limit $(0.05$ on the basis of $95 \%$ confidence level)

Therefore, $\quad \mathrm{n}=8,000,000 / 1+8,000,000$ $(0.05)^{2}$

$\mathrm{n}=8,000,000 / 20001$

Data Analysis and Discussion of Findings

Table1: There is an extent to which the imposition of environmental tax on nylon packages reduces flood.

\begin{tabular}{|ll|l|l|l|l|}
\hline & Frequency & Percent & Valid Percent & Cumulative Percent \\
\hline Valid & Strongly Agree & 68 & 32.7 & 32.7 & 32.7 \\
& Agree & 84 & 40.4 & 40.4 & 73.1 \\
Undecided & 20 & 9.6 & 9.6 & 82.7 \\
Disagree & 21 & 10.1 & 10.1 & 92.8 \\
Strongly Disagree & 15 & 7.2 & 7.2 & 100.0 \\
Total & 208 & 100.0 & 100.0 & \\
\hline
\end{tabular}

Source: Field Survey (2013)

From the table above, the following can be deduced. Out of the 400 copies of questionnaire administered, only 231 copies were retrieved with 23 copies not properly filled. Therefore, a total of 208 copies representing $52 \%$ were used for the analysis. 68 respondents and 84 representing $73.1 \%$ of the respondents either agreed or strongly agreed with the opinion that the imposition of environmental tax on nylon packages will reduce flood in Lagos State. Nevertheless,

$$
\mathrm{n}=400
$$

Using a population of approximately $8,000,000$ Lagosians with an error limit of $5 \%$, a sample size of 400 is considered adequate as computed above. A Wellorganized closed ended questionnaire is therefore designed and administered to provide answers to relevant questions emanating from the analysis of the problem.

The Spearman Rank Order Correlation which is a non-parametric test is used to measure the degree of association between the dependent and the independent variables in this study regardless of this representation by the respondents on the above subject matter, 20 representing $9.6 \%$ of the respondents remain undecided, and another 36 representing $17.3 \%$ either disagree or strongly disagree. From the result obtained, though over $73 \%$ agreed with the notion, there is still about $17 \%$ who disagreed. But, it is still valid to conclude that there is an extent to which the imposition of environmental tax on nylon packages can reduce flood. 
Table 2: The enlightenment of people on waste disposal can reduce flood.

\begin{tabular}{|ll|l|l|l|l|}
\hline & Frequency & Percent & Valid Percent & Cumulative Percent \\
\hline Valid & Strongly Agree & 78 & 37.5 & 37.5 & 37.5 \\
& 112 & 53.8 & 53.8 & 91.3 \\
Agree & 10 & 4.9 & 4.9 & 96.2 \\
Undecided & 2 & 1.0 & 1.0 & 97.2 \\
Disagree & 6 & 2.9 & 2.9 & 100.0 \\
Strongly Disagree & 208 & 100.0 & 100.0 & \\
Total & &
\end{tabular}

Source: Field Survey (2013)

From the result obtained above, the following can be deduced. Out of the 208 respondents used for the analysis, 190 representing $91.3 \%$ of the respondents either agreed or strongly agreed with the notion that to a great extent, the enlightenment of people on waste disposal will reduce flood. Nevertheless, regardless of this very high representation by the respondents on the above subject matter, 10 representing $4.9 \%$ of the respondents were undecided or indifferent, while 8 representing $3.9 \%$ either disagreed or strongly disagreed. From the result obtained, it is affirmative with certainty to conclude that the enlightenment of people on waste disposal to a great extent will reduce flood. This is based on the fact that a large percentage (91.3) of the respondents is in concurrence with the argument that the enlightenment of people on waste disposal will reduce flood to a great extent.

Table 3: Spearman Correlation for Environmental Tax on nylon packages and reduction of flood

\begin{tabular}{|c|c|c|c|c|}
\hline & & & $\begin{array}{l}\text { Nylon Packaging } \\
\text { plays an important } \\
\text { role in the } \\
\text { reduction of flood }\end{array}$ & $\begin{array}{l}\text { There is an extent to which } \\
\text { the imposition of } \\
\text { environmental tax on nylon } \\
\text { packages reduces flood }\end{array}$ \\
\hline \multirow[t]{6}{*}{$\begin{array}{l}\text { Spearman' } \\
\text { s rho }\end{array}$} & \multirow{3}{*}{$\begin{array}{l}\text { Nylon Packaging plays } \\
\text { an important role in the } \\
\text { reduction of flood }\end{array}$} & $\begin{array}{l}\text { Correlation } \\
\text { Coefficient }\end{array}$ & 1.000 & $.398^{* *}$ \\
\hline & & Sig. (2-tailed) & . & .000 \\
\hline & & $\mathrm{N}$ & 208 & 208 \\
\hline & \multirow{3}{*}{$\begin{array}{l}\text { There is an extent to } \\
\text { which the imposition of } \\
\text { environmental tax on } \\
\text { nylon packages reduces } \\
\text { flood }\end{array}$} & $\begin{array}{l}\text { Correlation } \\
\text { Coefficient }\end{array}$ & $.398^{* *}$ & 1.000 \\
\hline & & Sig. (2-tailed) & .000 & \\
\hline & & $\mathrm{N}$ & 208 & 208 \\
\hline
\end{tabular}

**. Correlation is significant at the 0.01 level (2tailed). 
From the output given in Table 3 , the correlation of environmental taxes on nylon packages and reduction of flood that is .398, which when squared, indicates $15.8 \%$ shared variance i.e. Coefficient of Determination is $0.158404 * 100=15.8 \%$.

This implies that environmental tax on nylon packages helps to explain over 15 per cent of the variance in respondent's scores on reduction of flood. With reference to the interpretations of Cohen (1988) cited in Uwuigbe, Uwuigbe \& Ajayi (2011), the findings revealed that there is a moderate positive correlation (Rs=.398, $\mathrm{p}<.005)$ between the imposition of environmental tax on nylon packages and reduction of flood and it is significant at 0.01 level.

Since Rs equals to 0.398 and it is greater than 0 (i.e. Rs $>0$, therefore the null hypothesis is rejected and the alternative hypothesis is accepted at 0.05 level of significance indicating 95\% confidence that the right decision was made. Therefore, charging a tax on nylon packages will aid the reduction of flood in Nigeria. The findings are in congruence with the findings of Hasson, Leiman and Visser (2007) and Dikgang and Visser (2010).

Table 4: Spearman Correlation for the enlightenment of people on waste disposal and the reduction of flood

\begin{tabular}{|c|c|c|c|c|}
\hline & & & $\begin{array}{l}\text { There is a significant } \\
\text { relationship between } \\
\text { the enlightenment of } \\
\text { people on waste } \\
\text { disposal and } \\
\text { reduction of flood }\end{array}$ & $\begin{array}{l}\text { There is an extent to } \\
\text { which the enlightenment } \\
\text { of people on waste } \\
\text { disposal reduces flood }\end{array}$ \\
\hline \multirow[t]{6}{*}{$\begin{array}{l}\text { Spearman' } \\
\text { s rho }\end{array}$} & \multirow{3}{*}{$\begin{array}{l}\text { There is a significant } \\
\text { relationship between the } \\
\text { enlightenment of people } \\
\text { on waste disposal and } \\
\text { reduction of flood }\end{array}$} & $\begin{array}{l}\text { Correlation } \\
\text { Coefficient }\end{array}$ & 1.000 & $.155^{* *}$ \\
\hline & & Sig. (2-tailed) & . & .002 \\
\hline & & $\mathrm{N}$ & 208 & 208 \\
\hline & \multirow{3}{*}{$\begin{array}{l}\text { There is an extent to which } \\
\text { the enlightenment of } \\
\text { people on waste disposal } \\
\text { reduces flood }\end{array}$} & $\begin{array}{l}\text { Correlation } \\
\text { Coefficient }\end{array}$ & $.155^{* *}$ & 1.000 \\
\hline & & Sig. (2-tailed) & .002 & \\
\hline & & $\mathrm{N}$ & 208 & 208 \\
\hline
\end{tabular}

**. Correlation is significant at the 0.01 level (2-tailed).

From the output given in Table 4, the correlation of enlightenment on waste disposal and reduction of flood that is .155 (Rs=.155, p<.005) which when squared indicates $2.4 \%$ percent shared variance i.e. Coefficient of Determination = $0.024025 * 100=2.4 \%$. The enlightenment on waste disposal explains over 2 percent of the variance in respondent's scores on reduction of flood. The Spearman Rank Correlation result shows that a weak but positive correlation exists between the two variables. This implies that a high level of enlightenment on waste disposal is associated with high reduction of flood and 
low level of enlightenment with low level of reduction of flood.

Since Rs=.155 and Rs is $>0$, therefore the null hypothesis is rejected and the alternative hypothesis is accepted at 0.05 level of significance indicating $95 \%$ confidence. These findings are in congruence with the proposition of Adedipe, Sridhar, Baker and Verma (2005) identified enlightenment as a pre- requisite to pollution control. The implication of these results is that for flood to be reduced, enlightenment on waste disposal has to be increased as improper waste disposal is a major cause of flood.

\section{Conclusion and Recommendations}

This study concludes that flood has been an issue of concern experienced all over the world including Nigeria, especially in the coverage area (Lagos State). Therefore, the implementation of environmental taxes on nylon will lead to an immense reduction in the use of nylon as the major packaging system in Nigeria, thereby reducing the amount of waste. This is because nylon constitutes a bulk of the waste and it is not easily decomposed. This as seen in Vietnam, will aid in the reduction of flood in Lagos State and in Nigeria as a whole, thereby making the area a safe place for habitation.

The study therefore recommends that the Federal Inland Revenue Service should embark on massive public enlightenment programme in order to educate and sensitize the populace about environmental taxation. Also, there should be a proper public enlightenment scheme to educate and sensitize the populace about waste disposal and how the disposal methods of the popularly patronised cart pushers in the long run can amplify flood. Finally, there should be a change in the packaging system in Nigeria as most of our products packaged in nylon while the adoption of paper bags or cloth bag which has been adopted in England should be emphasised.

\section{References}

1. Adedipe, N.O, Sridhar, M.K.C., Baker, J. and Verma, M. (2005), Waste Management, Processing and Detoxification, Ecosystems and Human Well-Being: Policy Responses, Chopra, K. (Eds), Washington, DC: Island Press

2. Aderogba, K. A. (2012), 'Substantive Causes and Effects of Floods in South Western Nigeria and Sustainable Development of the Cities and Towns,' Journal of Emerging Trends in Educational Research and Policy Studies, 3 (6), 551-560

3. Agidee, Y. (2013, February 28), 'The Menace of Plastic Bags,' The Punch. [Online], [Retrieved September 28, 2013], http://www.punchng.com.

4. Akinbola, B. R. (2009) 'Waste Environmental Law: Emerging Trends and Implication in Nigeria,' International Journal of Environmental, 6 (1\&2), 82-99.

5. Alcalde, J., Corchon, L. C. and Moreno, B. (1998), 'Pigouvian Taxes: A Strategic Approach,' [Online], [Retrieved August 15, 2013]

http://www.eco.uc3m.es/temp/pigouvianta xes.pdf

6. Babatunde, M.A and Biala, M.I (2010), 'Externality Effects of Sachet Water Consumption and the Choice of Policy Instruments in Nigeria: Evidence from Kwara State,' Journal of Economics, 1 (2), 113-131. [Online], [Retrieved September 28, 2013], http:// www.krepublishers.com/:journals

7. Coxhead, I. and Chan, N.V. (2011), 'Vietnam's New Environmental Tax Law: What Will it Cost? Who Will Pay?' University of Wisconsin, Madison Department of Agricultural and Applied Economics, Staff Paper No. 561, [Online], [Retrieved August 28, 2013], http://www.aae.wisc.edu/pubs/sps/pdf/stp ap561.pdf 
8. Dia, M.A., Wernerman, J., Grigoryan, A., Becchi, G., and Jung, C (2012), Disaster Risk Reduction Capacity Assessment. National Capacity Assessment Report, Federal Republic of Nigeria,' [Online], [Retrieved September 28, 2013] http://www.preventionweb.net/.../28963_2 8963nigeriaeprdrrcapacityassessment.

9. Dikang, J. \& Visser, M. (2010), 'Behavioural Response to Plastic Bag Legislation in Botswana. Environment for Development, Discussion Paper Series. 367,' [Online], [Retrieved August 28 http://www.sandeeonline.org/.../954_PUB_ WP_65_Kanupriya_Gupta

10. Etuonovbe, A.K. (2011), 'The Devastating Effect of Flooding in Nigeria. A paper presented during the FIG, 56, 18-22,' [Online], [Retrieved September 20, 2013], http://www.fig.net.pub.fig2011papers.ts06j_ etuonovbe+5602pdf

11. European Environment Agency (1996), 'Environmental Taxes: Implementation and Environmental Effectiveness. Environmental Issues,' Series, 11, EEA, Luxembourg,' [Online], [Retrieved August 26, 2013], http://www.geota.pt/rfa/docs/gt

12. European Environment Agency (2000), 'Environmental Taxes: Recent Development in Tools for Integration, Environmental Issues Series, 18,' [Online], [Retrieved September 18, 2013], http://www.geota.pt/rfa/docs/gt.

13. Eurostat (2001), 'Environmental taxes- A Statistical Guide,' [Online], [Retrieved September 18, 2013], http://www.eurostat.com

14. Fullerton, D. (1996), 'Why have separate environmental taxes? National Bureau of Economic Research,' 10 (1), 33-70.

15. Fullerton, D., Leicester, A. and Smith, S. (2007, March 22), 'Environmental Taxes, Paper Written for the Mirrless Review, Reforming the Tax System for the 21st
Century,' [Online], [Retrieved September 18, 2013], www.ifs.org.uk/mirrleesreview

16. Hasson, R., A. Leiman and M. Visser. (2007), 'The Economics of Plastic Bag Legislation in South Africa,' South African Journal of Economics, 75, 66-83.

17. Kasum, A.S. (2010), 'Environmental Degradation Problems caused by Human Activities in Nigeria: Enforced (taxation) versus Voluntary (Social Responsibility) Solution,' International Journal of Banking, Accounting and Finance, 2(3) 236250

18. Nye,J.V.(2008), 'The Pigou Problem,' [Retrieved September 16, 2013], http://www.cato.org/sites/cato.org/files/se rials/files/regulation/6/v31n2-5.pdf

19. OECD (2001), 'Environmentally Related Taxes in OECD Countries, Issues and Strategies,' [Online], [Retrieved August 26, 2013], http://www.oecd.org

20. Ojeifo, O.M \& Uwadie, B.T. (2001), 'Waste Disposal Problems in Emerging Urban Centres: The case of Ekpoma and Irrua in Edo State,' International Journal of Environment and Development, 6(2), 65-72.

21. Olufowobi, S. (2012, August 24), 'Government Pleads with Residents on Waste Disposal' [Online], The Punch, [Retrieved August 28, 2013], http://www.punchng.com/aug/28

22. Olusegun, A. A. (2012), 'An Evaluation of the Interventionist Reforms by the Lagos State Government towards Achieving Millennium Development Goals (MDGS) in Environmental Sanitation and Hygiene Practice,' International Journal of Humanities and Social Science, 2(16), 121136.

23. Omole, D. O. and Isiorho, S. (2011), 'Waste Management and Water Quality issues in Coastal States of Nigeria: The Ogun 
state experience,' Journal of Sustainable Development in Africa, 13 (6), 207-217.

24. Sollund, S. (2007), 'Environment taxes, Paper presented at IFAD meeting of United Nations Group of Experts on Domestic Resource. [Online], [Retrieved September 12, 2013],

http://www.un.org/esa/ffd/tax/2007DRM_SE G/05EnvironmentalTaxes.doc

25. Uwuigbe, U. (2009), 'An Evaluation of Stakeholders and Accounting Teachers' Perception on Corporate Social Environmental Disclosure Practice in Nigeria,' International Journal of Distance Education, 4(1), 46-53

26. Uwuigbe, U (2012), 'Environmental Accounting: A Tool for Promoting Environmental Management in the Niger Delta,' Manager Journal, 15, 202-211

27. Uwuigbe, U (2012), 'Web-Based Corporate Environmental Reporting in
Nigeria: A Study of Listed Companies,' Informatica Economică, 1(3), 27-36

28. Uwuigbe, U. Jimoh, J., Daramola, S. \& P. (2013), 'Corporate Environmental Accounting Practice in 'Nigeria: A Comparative Study of the Perception of Prepares and Users,' International Journal of Social Sciences and Humanities Reviews, 4 (3), 140-14

29. Uwuigbe, U., Olubukunola, U., \& Ajayi, 0. A. (2011), 'Corporate Social Responsibility Disclosures by Environmentally Visible Corporations: A Study of Selected Firms in Nigeria,' European Journal of Business and Management, 3 (9) 9-17.

30. Wang, J., Ge, C., Gao, S \& Zhao,Y. (2005). 'Design on the framework of china environmental taxation policy and its implementation strategy'. Paper based on a project funded by National Key Researches Program by Chinese Government.

Uwuigbe Uwalomwa, Uwuigbe Olubukunola Ranti and Iyoha Francis (2015), Journal of South African Business Research, DOI: 10.5171/2015.645670 